\title{
MULTIFUNCTIONAL COMPUTER TABLE
}

\author{
Ahasan Habib ${ }^{1}$, Ghazi Abu Taher², Moumita Saha \\ ${ }^{1}$ Lecturer, Industrial Engineering \& Management, Khulna University of Engineering \& Technology, Khulna, Bangladesh, \\ shiplu04_ipe@yahoo.com \\ ${ }^{2,3} 3^{\text {rd }}$ year Student, BSC, Industrial Engineering \& Management, Khulna University of Engineering \& Technology, \\ Khulna, Bangladesh, ghaziabutaher@yahoo.com,moumita.saha777@gmail.com
}

\begin{abstract}
In this paper simple design has obtained to reduce the cost and space of computer table. Our product multifunctional computer table is a combine form of projector table, computer table, reading and writing table. This table can be made by using different types of materials. We have discussed all the steps of making this product. We have also discussed all the steps of making this product. We have also discussed the economic calculation and customers' need. We have done a lot of surveys and included the survey chart. After doing all this, we think that this product will be a real market capturing product.
\end{abstract}

Keywords: Multifunctional computer table and it's parts, Features of multifunctional computer table, Mission statement, Capturing the "Voice of customer", House of quality(HOQ) of multifunctional computer table, Fishbone diagrams, Concept selection, Screening process, Scoring process, Bill of material, Break-even point

\section{INTRODUCTION:}

The computer desk and related ergonomic desk are furniture pieces designed to comfortably and aesthetically provide a working surface and house or conceal office equipment including computers, peripherals and cabling for office and home-office users. The most common form of the computer desk is a variant of the ergonomic desk, which has an adjustable keyboard tray and sufficient desktop space for handwriting. Provisions for a monitor shelf and holes for routing cables are integrated in the design, making it easier to connect the computer components together. The typical armoire desk provides space for a keyboard, mouse, monitor, printer and speakers. Cubicle desk designs for business and government workplaces include a range of shelves, trays and cable-routing holes for computer systems. In some computer desks, the cabling is affixed to the modesty panel at the back of the desk, to create a neater appearance.

There are a great variety of computer desk shapes and forms. Large multi-student computer desks configured in rows are designed to house dozens of computer systems while facilitating wiring, general maintenance, theft prevention and vandalism reduction. Small rolling lectern desks or computer carts with tiny desktops provide just enough room for a laptop computer and a mouse pad. Computer desks are typically mass-produced and require some self-assembly. The ergonomic desk is a modern desk form which, like the adjustable drawing table or drafting table, offers mechanical adjustments for the placement of its elements in order to maximize user comfort and efficiency. The ergonomic desk is usually a "stand-alone" piece of furniture allowing access to the adjustment mechanisms. Some ergonomic desks have a sufficiently large desktop height adjustment to create either a common "sit-down" desk or a less common standing desk, which allows the user to work while standing.

Our product Multifunctional Computer Table provides both computer desk facility and ergonomic desk facility. There is no need of extra table and spend extra money for obtaining both facility at a time.

\section{MULTIFUNCTIONAL COMPUTER TABLE}

\section{AND IT'S PARTS}

Our product is a computer table in combination with reading and writing facilities. Computer table is an existing product. We modified it in some ways. We included some features that increase its functional capacity. So our product holds in derivatives of existing platform and incremental improvement of existing product categories. We included some new parts like a sliding upper portion where we put monitor of computer, an external flat portion to write something when we uses computer, a cabinet to keep the projector and a moveable reflecting hole to project the projector, some drawers to keep our essential goods and an drawers to keep our keyboard and mouse. Our product includes some extra facilities that the existing product in the market can't have those. It's fulfilled the demand of time. In a word it's a multifunctional computer table. 

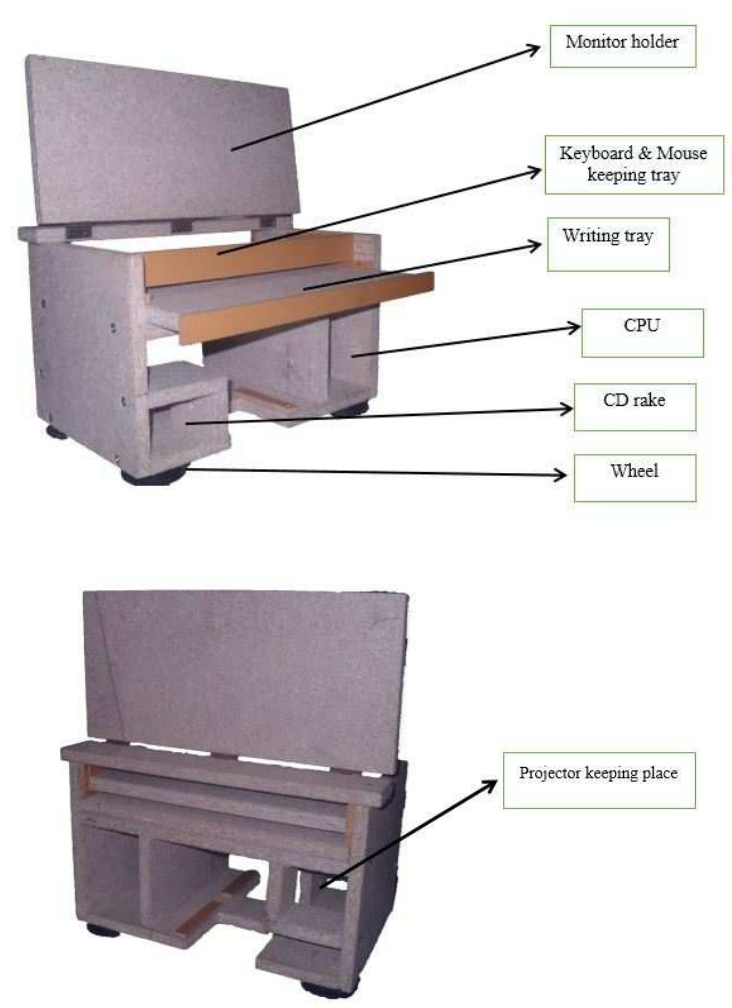

Fig -1: Multifunctional computer table (front view and rear view).

\section{FEATURES OF MULTIFUNCTIONAL}

\section{COMPUTER TABLE}

i) The computer table has good computer keeping facilities.

ii) The table has projector keeping space.

iii) The table has extra drawers to keep important documents.

iv) The table has space to keep CDs.

v) The table has wheels to move it from one place to another.

vi) The table has extra part for writing and reading.

vii) The table good space for keeping mouse and key board.

This table has more features than a normal computer table.

Those features are

i Computer table with reading facility.

ii Projector chamber.

iii Providing feasibility of using.

iv Good ergonomics.

V Space consuming.

vi Cost reduction.

\section{MISSION STATEMENT}

While developing this product Multifunctional Computer table, we have found a mission statement. That is added below-

Table- 1: Mission statement of Multifunctional computer table.

\begin{tabular}{|c|c|}
\hline \multicolumn{2}{|c|}{ Mission Statement: Multifunctional Computer Table } \\
\hline Product description & $\begin{array}{l}\text { Computer table with reading } \\
\text { and writing facilities, } \\
\text { projector keeping facilities. }\end{array}$ \\
\hline Benefit Proposition & $\begin{array}{l}\text { Multiple working functions in } \\
\text { one table, saves money and } \\
\text { space. }\end{array}$ \\
\hline Key Business Goals & $\begin{array}{l}\text { Serve as platform for Office } \\
\text { equipment. }\end{array}$ \\
\hline Primary Market & $\begin{array}{l}\text { Can capture the market of } \\
\text { educational institutions; cover } \\
\text { the needs of family, } \\
\text { environmentally friendly. }\end{array}$ \\
\hline Secondary Markets & Office equipment market. \\
\hline $\begin{array}{l}\text { Assumptions and } \\
\text { Constraints }\end{array}$ & $\begin{array}{l}\text { New product platform, space } \\
\text { reducing thinking, all the } \\
\text { components can be easily } \\
\text { made by wood with the help } \\
\text { of carpenter. }\end{array}$ \\
\hline Stakeholders & $\begin{array}{l}\text { Purchasers and users } \\
\text { manufacturing operations, } \\
\text { service operations, distributors } \\
\text { and sellers. }\end{array}$ \\
\hline
\end{tabular}

\section{CAPTURING THE "VOICE OF THE}

\section{CUSTOMER"}

While finding the additional features we have met and interviewed a lot of customers. We have gathered raw data from them. They give statements, advices, and needs of their interest, problems and much useful information. Analyzing all the statements we have made a chart. We have also observed the existing products. The chart is given below-

Table- 2: customer data template filled in with sample customer statements and interpreted needs.

\begin{tabular}{|c|l|l|}
\hline Question/Prompt & \multicolumn{1}{|c|}{$\begin{array}{c}\text { Customer } \\
\text { Statement }\end{array}$} & \multicolumn{1}{|c|}{$\begin{array}{c}\text { Interpreted } \\
\text { Need }\end{array}$} \\
\hline Typical users & $\begin{array}{l}\text { I need to keep } \\
\text { essential things } \\
\text { like pen, paper } \\
\text { etc. }\end{array}$ & $\begin{array}{l}\text { There is small } \\
\text { section under the } \\
\text { projector plot. }\end{array}$ \\
\hline
\end{tabular}




\begin{tabular}{|c|c|c|}
\hline & $\begin{array}{l}\text { The table should } \\
\text { be multiple } \\
\text { working } \\
\text { facilities. }\end{array}$ & $\begin{array}{l}\text { The table } \\
\text { consumes the } \\
\text { space for } \\
\text { containing } \\
\text { multiple facilities. }\end{array}$ \\
\hline & $\begin{array}{l}\text { I need to move it } \\
\text { easily. }\end{array}$ & $\begin{array}{l}\text { The table has } \\
\text { wheels so that it } \\
\text { can move easily. }\end{array}$ \\
\hline \multirow{3}{*}{ Likes } & $\begin{array}{l}\text { I like the } \\
\text { projector keeping } \\
\text { facilities. }\end{array}$ & $\begin{array}{l}\text { Don't need to buy } \\
\text { extra projector } \\
\text { table. }\end{array}$ \\
\hline & $\begin{array}{l}\text { I like the writing } \\
\text { fact. }\end{array}$ & $\begin{array}{l}\text { Don't need to buy } \\
\text { extra writing and } \\
\text { reading table. }\end{array}$ \\
\hline & $\begin{array}{l}\text { I like to keep the } \\
\text { CDs. }\end{array}$ & $\begin{array}{l}\text { Don't need to buy } \\
\text { extra CD rake. }\end{array}$ \\
\hline \multirow[b]{2}{*}{ Dislikes } & $\begin{array}{l}\text { I need to keep } \\
\text { essential things } \\
\text { like pen, paper } \\
\text { etc. }\end{array}$ & $\begin{array}{l}\text { There is small } \\
\text { section under the } \\
\text { projector plot. }\end{array}$ \\
\hline & $\begin{array}{l}\text { The table should } \\
\text { be multiple } \\
\text { working } \\
\text { facilities. }\end{array}$ & $\begin{array}{l}\text { The table } \\
\text { consumes the } \\
\text { space for } \\
\text { containing } \\
\text { multiple facilities. }\end{array}$ \\
\hline $\begin{array}{c}\text { Suggested } \\
\text { improvements }\end{array}$ & $\begin{array}{l}\text { I need to move it } \\
\text { easily. }\end{array}$ & $\begin{array}{l}\text { The table has } \\
\text { wheels so that it } \\
\text { can move easily. }\end{array}$ \\
\hline
\end{tabular}

By interpreting the data in terms of customer needs we have results and those are given below-

Table- 3: comparing the customer statements with our product.

\begin{tabular}{|l|l|l|l|}
\hline Guide line & $\begin{array}{l}\text { Customer } \\
\text { statement }\end{array}$ & $\begin{array}{c}\text { Need } \\
\text { Statement } \\
\text { Right }\end{array}$ & $\begin{array}{c}\text { Need } \\
\text { Statement } \\
\text { Wrong }\end{array}$ \\
\hline $\begin{array}{l}\text { "What" } \\
\text { not "how" }\end{array}$ & $\begin{array}{l}\text { There is no } \\
\text { foportunity } \\
\text { for writing } \\
\text { and reading } \\
\text { in my } \\
\text { computer } \\
\text { table. }\end{array}$ & $\begin{array}{l}\text { Our table has } \\
\text { both writing } \\
\text { and reading } \\
\text { facilities and } \\
\text { using } \\
\text { computer at } \\
\text { the same time. }\end{array}$ & $\begin{array}{l}\text { This type of } \\
\text { table is } \\
\text { unavailable } \\
\text { in the } \\
\text { market. }\end{array}$ \\
\hline
\end{tabular}

\begin{tabular}{|c|l|l|l|}
\hline Specificity & $\begin{array}{l}\text { I change } \\
\text { frequently } \\
\text { the location } \\
\text { of my } \\
\text { computer } \\
\text { table. }\end{array}$ & $\begin{array}{l}\text { Our table has } \\
\text { wheels so that } \\
\text { we can move } \\
\text { it easily from } \\
\text { one place to } \\
\text { another. }\end{array}$ & $\begin{array}{l}\text { The table is } \\
\text { not possible } \\
\text { to move } \\
\text { without } \\
\text { wheel. }\end{array}$ \\
\hline $\begin{array}{c}\text { Positive } \\
\text { not } \\
\text { negative }\end{array}$ & $\begin{array}{l}\text { I need } \\
\text { different } \\
\text { radii when I } \\
\text { use my }\end{array}$ & $\begin{array}{l}\text { Our table has } \\
\text { enough } \\
\text { facilities for } \\
\text { the best use of } \\
\text { projector. }\end{array}$ & $\begin{array}{l}\text { The table } \\
\text { has not } \\
\text { fewer } \\
\text { facilities for } \\
\text { the rotation } \\
\text { of projector } \\
\text { at different } \\
\text { angles. }\end{array}$ \\
\hline $\begin{array}{c}\text { An } \\
\text { attribute of } \\
\text { the } \\
\text { product }\end{array}$ & $\begin{array}{l}\text { keep my } \\
\text { CDs on my } \\
\text { computer } \\
\text { table. }\end{array}$ & $\begin{array}{l}\text { A section has } \\
\text { been provided } \\
\text { to keep CDs. }\end{array}$ & $\begin{array}{l}\text { Our table } \\
\text { has section } \\
\text { to keep } \\
\text { CDs. }\end{array}$ \\
\hline $\begin{array}{c}\text { Avoid" } \\
\text { "should" and }\end{array}$ & $\begin{array}{l}\text { keyboard } \\
\text { and mouse } \\
\text { drawers } \\
\text { stuck } \\
\text { sometimes } \\
\text { and I hate it. }\end{array}$ & $\begin{array}{l}\text { The drawers } \\
\text { are of sliding } \\
\text { type that avoid } \\
\text { stucking } \\
\text { problem. }\end{array}$ & $\begin{array}{l}\text { The } \\
\text { drawers } \\
\text { should be } \\
\text { of sliding } \\
\text { type. }\end{array}$ \\
\hline
\end{tabular}

After that we have organized the needs into hierarchy and established the relative importance of the product. After organizing the needs we have got-

$>$ Use computer table as a reading table

i. An LCD monitor is attached below the folding part of the table.

ii. A safety clamp is used to hold the folding part at the suitable position.

Save money and space

i. Use same table as the purpose of reading, writing and computer table.

Easy to move

i. Number of wheels help for the movement of the table.

Use as a projector table

i. Using the projector increases the professional activities.

ii. Use the table for official purpose as well as household product.

The writing trey can move 
i. The trey can be placed on the suitable position when user wants to write something.

$>$ Easy to set up and use

i. User can use the table easily and comfortably.

ii. There is no complexity for using.

iii. It is easy to turn on.

$>$ Safe to use

i. The table is safe to use.

ii. Wooden boards of the table are useful to hold every component of computer.

Easy to store

i. Wood of the table is noncorrosive.

The table looks like a professional quality product.

\section{HOUSE OF QUALITY (HOQ) OF}

\section{MULTIFUNCTIONAL COMPUTER TABLE:}

Once customer needs are identified, preparation of the product planning matrix or "house of quality" can begin. Customer needs or requirements are stated on the left side of the matrix. These are organized by category based on the affinity diagrams.

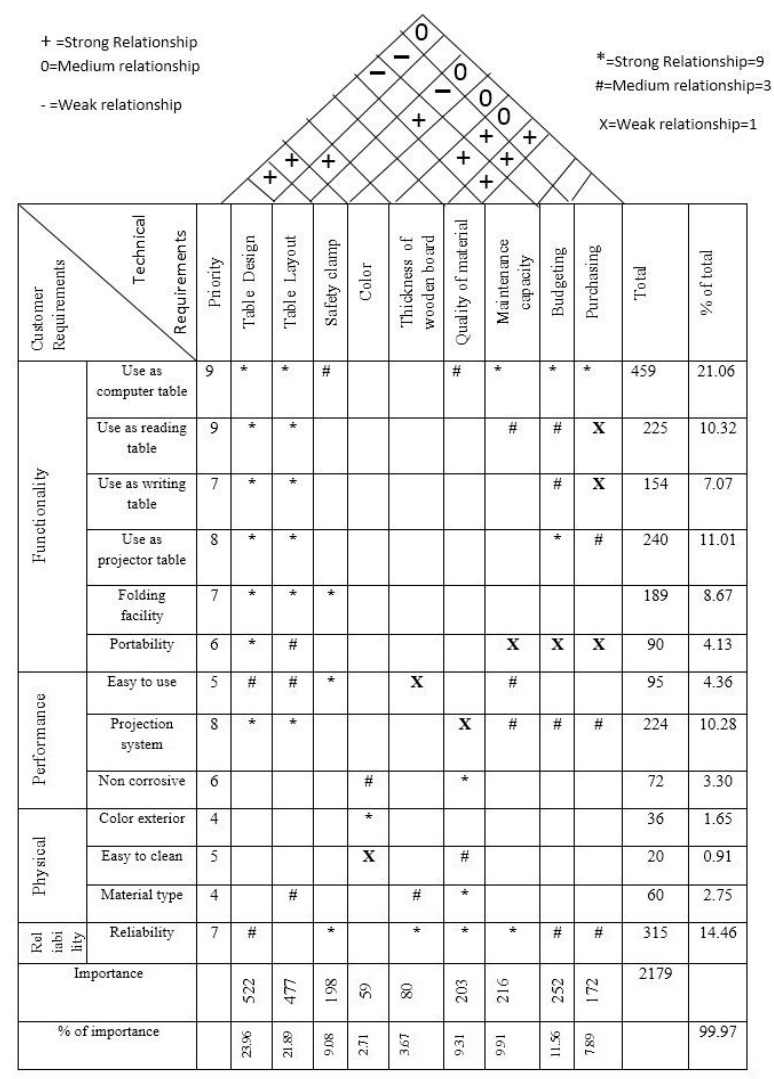

Chart-1: HOQ of Multifunctional computer table.

\section{CONCEPT GENERATION OF MULTIFUNCTIONAL COMPUTER TABLE:}

Everything is involved with different types of problem. We have tried to find the problem of our product. Finding the problem can solve the problems easily. For this process we have adopted some ways. They are:

\subsection{Brainstorming}

Brainstorming is a process for developing creative solutions of problem.

$>$ There indicate some problem on hinge, safety clamp, wheel and wooden board.

- Difficult to find suitable hinges which are made of non-corrosive metal.

- Difficult to find suitable safety clamp which is made of non-corrosive metal.

- Difficult to find suitable wheels which are made of high quality polymer composite.

- Wooden board creates imbibition problem.

- There may be some complexity of projection as the system is not feasible with the setup of projector in the table.

By brainstorming, main problem is selected that mentioned below:

- The wheel might be broken for bearing excessive load as the wood is heavy in weight.

- Wooden board creates imbibition problem that occurs corrosion on the metal attached in the table.

- Wood that is used for manufacturing the table is costly.

To avoid all these problems partex board can be used instead of wooden board.

\subsection{Scamper}

Table-4: Scamper.

\begin{tabular}{|c|c|l|}
\hline \multirow{2}{*}{$\mathrm{S}$} & \multirow{3}{*}{ Substitute } & $\begin{array}{l}\text { What can we substitute to } \\
\text { make an improvement? }\end{array}$ \\
\cline { 3 - 3 } & $\begin{array}{l}\text { We substitute partex } \\
\text { board instead of wooden } \\
\text { board. }\end{array}$ \\
\hline \multirow{2}{*}{$\mathrm{C}$} & \multirow{2}{*}{ Combine } & $\begin{array}{l}\text { What materials can we } \\
\text { combine? }\end{array}$ \\
\cline { 3 - 3 } & & $\begin{array}{l}\text { We use non-ferrous metal } \\
\text { for hinge, safety clamp \& } \\
\text { screw and use high } \\
\text { quality polymer } \\
\text { composite for wheel. }\end{array}$ \\
\hline \multirow{2}{*}{ A } & Adapt & $\begin{array}{l}\text { What part of the table } \\
\text { could we change? }\end{array}$ \\
\hline
\end{tabular}




\begin{tabular}{|c|c|c|}
\hline & & $\begin{array}{l}\text { The table has a separate } \\
\text { tray for writing. }\end{array}$ \\
\hline \multirow[b]{2}{*}{ M } & \multirow[b]{2}{*}{ Modify } & $\begin{array}{l}\text { What will happen if we } \\
\text { modify the table? }\end{array}$ \\
\hline & & $\begin{array}{l}\text { The table can be used for } \\
\text { multifunctional purpose. }\end{array}$ \\
\hline \multirow[b]{2}{*}{$\mathrm{P}$} & \multirow[b]{2}{*}{$\begin{array}{l}\text { Put to Other } \\
\text { purpose }\end{array}$} & $\begin{array}{l}\text { Who else might be able to } \\
\text { use it? }\end{array}$ \\
\hline & & $\begin{array}{l}\text { The table can be used for } \\
\text { both domestic and official } \\
\text { purpose. }\end{array}$ \\
\hline \multirow[b]{2}{*}{ E } & \multirow[b]{2}{*}{ Eliminate } & $\begin{array}{l}\text { What would happen if we } \\
\text { removed a component? }\end{array}$ \\
\hline & & $\begin{array}{l}\text { The table cannot be } \\
\text { moved easily without } \\
\text { wheels. }\end{array}$ \\
\hline \multirow{2}{*}{$\mathrm{R}$} & \multirow{2}{*}{ Reverse } & $\begin{array}{l}\text { What will happen if we } \\
\text { use the other way? }\end{array}$ \\
\hline & & $\begin{array}{l}\text { The table will lose its } \\
\text { utility. }\end{array}$ \\
\hline
\end{tabular}

\subsection{Research}

By researching the problem is selected to the material selection of the table.

- If we use iron, corrosion would be occurred.

- If we use high quality polymer which can increase the strength of the wheel.

- If we use partex board in the table there wouldn't occur imbibition and ensure good appearance

So we decided to use non-ferrous metal, high quality polymer and partex board.

\subsection{User Narrative}

We made some instruction to follow and make advertisement to create user and to make it easy for use and feel it's necessary. For that reason, we will maintain some step:

- Provide guide book.

- User manual.

- Instruction for proper use when it is to buy.

- Campaign and monitoring.

\subsection{User Creation}

We are working to produce MTB (make to buy) categorized product. But we get the plan by MTE (make to engineering) to adding special feature in our computer table. We are trying to increase fusibility of existing product with extra facilities.

\subsection{Description Recombination}

It is a process of combining ideas observing or gaining the all data from all individual members belongs the team for the multifunctional computer table. We recombined our data from the initial steps of brainstorming. This is necessary to get specific decision to produce final product. We finally come to the decision to use non-ferrous metallic components, high quality polymer component and partex board.

\subsection{Concept Classification Tree}

Concept classification tree of Multifunctional computer table is given below-

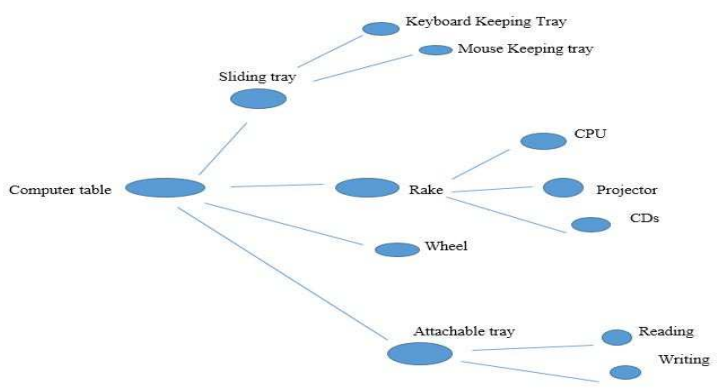

Figure-2: Concept classification tree.

\subsection{Concept Combination Table}

Concept combination of Multifunctional computer table is given below-

Table-5: Concept combination table.

\begin{tabular}{|c|c|c|}
\hline $\begin{array}{c}\text { Main parts of } \\
\text { Computer table }\end{array}$ & Accessories & Application \\
\hline $\begin{array}{c}\text { Monitor } \\
\text { Keeping Board }\end{array}$ & Hinge & $\begin{array}{c}\text { To fold the } \\
\text { board }\end{array}$ \\
\hline Main Frame & nuts and bolts & $\begin{array}{c}\text { To join the } \\
\text { body }\end{array}$ \\
\cline { 2 - 3 } & Screws & $\begin{array}{c}\text { To support the } \\
\text { body }\end{array}$ \\
\hline Wheel & & $\begin{array}{c}\text { To move the } \\
\text { table }\end{array}$ \\
\hline
\end{tabular}

\subsection{Brain Writing}

We made a documentary form of our ideas obtained by brain storming. We wrote all members ideas and plans to make our product finally. We listed the ideas of designing of final product, procedure to make true our desired product, market taking steps etc.

\begin{tabular}{|c|l|}
\hline \multicolumn{2}{|c|}{ ○ Complexity in hanging monitor in the table } \\
\hline By attaching clamp & By using hook \\
\hline \multicolumn{2}{|c|}{ Risk in folding system } \\
\hline By using safety clamp & $\begin{array}{l}\text { Providing suitable space for } \\
\text { monitor on the table }\end{array}$ \\
\hline
\end{tabular}




\subsection{Fishbone Diagram /Cause \& Effect Diagram /}

\section{Root Cause Analysis}

After analyzing we have got various causes and their effects which might create problems in the production process. Here are given some fishbone diagrams below-

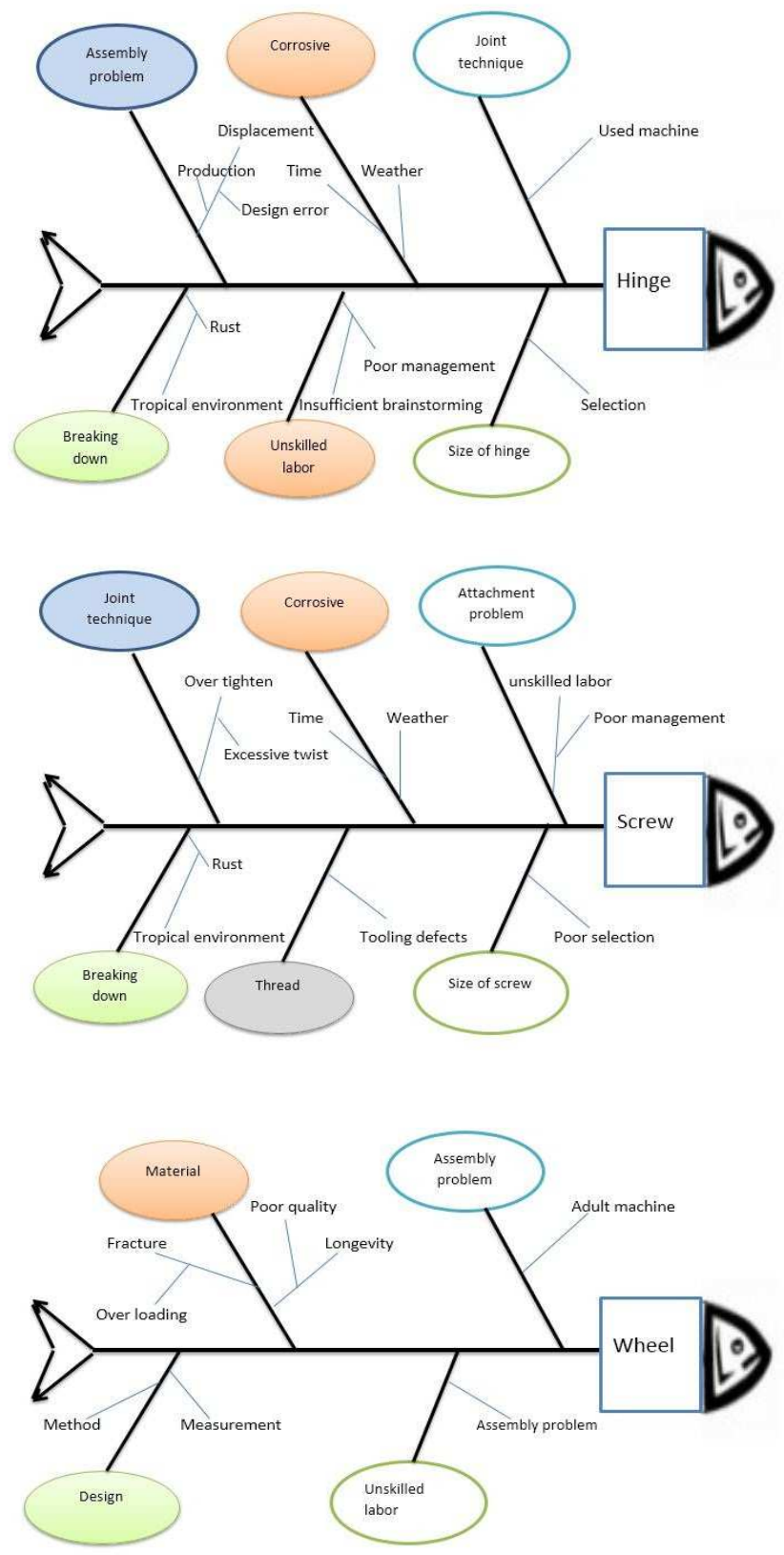

Figure-3: Fishbone diagram of Multifunctional computer table.

\section{CONCEPT SELECTION}

Concept selection is often performed in a two stages as way to manage the complexity of evaluating dozens of product concept. Each is supported by a decision matrix which is used by the term to rate, rank and select the best concepts.

\subsection{Screening Process}

This technique narrows the number of concepts quickly and improves them. After screening the concepts we found the rank which is given below-

Table-6: Concept screening process.

\begin{tabular}{|l|c|}
\hline \multicolumn{1}{|c|}{ Concepts } & Rank \\
\hline Table design & 1 \\
\hline Wheel & 2 \\
\hline Screw & 2 \\
\hline Safety clamp & 4 \\
\hline Quality of material & 4 \\
\hline Folding facility & 6 \\
\hline Multifunctional uses & 6 \\
\hline
\end{tabular}

\subsection{Scoring Process}

It is used for differentiate better resolution among competing concepts. After scoring the concepts we found the rank which is given below-

Table-7: Concept scoring process.

\begin{tabular}{|l|c|}
\hline \multicolumn{1}{|c|}{ Concepts } & Rank \\
\hline Multifunctional uses & 1 \\
\hline Quality of material & 2 \\
\hline Table design & 3 \\
\hline Wheel & 4 \\
\hline Folding facility & 5 \\
\hline Safety clamp & 5 \\
\hline Screw & 7 \\
\hline
\end{tabular}

Finally we decided to develop three features i.e. multifunctional uses, quality of material and table design from the combination of above table and these three features are within our cost and manufacturing capability.

\section{CONCEPT TESTING}

We communicated the concept with the customer by verbal description, sketch, photos and rendering, simulation, physical appearance models etc. We made a storyboard for advertising our product. 


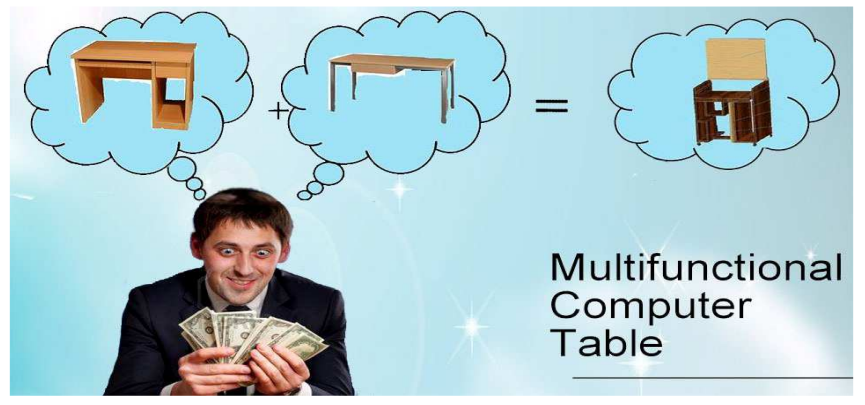

Figure-4: Storyboard of our product.

We also made a working prototype.

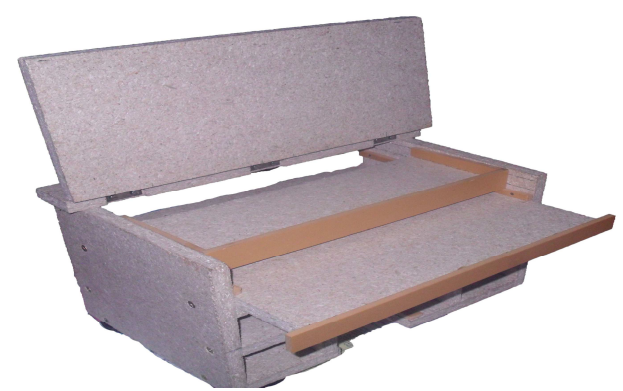

Figure-5: Working prototype of our product.

By surveying over the population we have taken smaller sample size because of its simplicity. So from a huge population we have taken a sample of small amount of students and some officials among the large people using both reading table and computer table in their house, offices and other phenomenon. Often a product addresses multiple market segments in such cases and accurate concept test requires that potential customers from each target segment be surveyed. Surveying every possible segment may be prohibitively expensive in cost or time, and in such cases the team may choose to survey potential customer from only the largest segment.

Form these data to collect form potential customer and nonpotential customers that give the appropriate result to the producers.

We estimate Q, the quantity of the product expected to be sold during a time period, as

\section{$\mathrm{Q}=\mathrm{N} * \mathrm{~A} * \mathrm{P}$}

$\mathrm{N}=$ No. of potential customers expected to make purchases during time period.

$A=$ Fraction of these potential customers or purchasers for which the product is available.

$\mathrm{P}=$ Probability that the product is purchased if available and if customers is aware of it.
$\mathrm{P}$ is estimated in turn by,

$$
\mathrm{P}=\mathrm{C}_{\text {definitly }} * \mathrm{~F}_{\text {definitely }}+\mathrm{C}_{\text {probably }} * \mathrm{~F}_{\text {probably }}
$$

Multifunctional computer table is sold to official, assume that the multifunctional computer table is sold in market at a rate of $15000 /=$ units per year. Assume that the table through a single distributor that accounts for 25 percent of the sales in category. Assume that results from a concept test with factory managers responsibly for purchasing transportation devices indicate a definitely would buy fraction of 0.30 and probably would buy fraction of 0.20 . If we use a value of 0.40 for $\mathrm{C}_{\text {definitly }}$ and 0.20 for $\mathrm{C}_{\text {probably }}$, then

$$
\begin{aligned}
& \mathrm{P}=(0.4 * 0.30)+(0.20 * 0.20)=0.16 \\
& \mathrm{Q}=15000 * 0.25 * 0.16=600 \text { units/year }
\end{aligned}
$$

If the table is sold to all students, assume that the multifunctional computer table is sold in market at a rate of $200000 /=$ units per year. Assume that we sample students in this second group that accounts for 30 percent of the sales in category. Assume that results from a concept test with factory managers responsibly for purchasing transportation devices indicate a definitely would buy fraction of 0.10 and probably would buy fraction of 0.05 . If we use a value of 0.40 for $\mathrm{C}_{\text {definitly }}$ and 0.20 for $\mathrm{C}_{\text {probably, }}$ then

$$
\begin{gathered}
\mathrm{P}=(0.4 * 0.10)+(0.20 * 0.05)=0.05 \\
\mathrm{Q}=200000 * 0.30 * 0.05=3000 \text { units } / \text { year }
\end{gathered}
$$

\section{ECONOMIC ANALYSIS OF}

\section{MULTIFUNCTIONAL COMPUTER TABLE}

This is the most important topic of product development process. Without calculating the Bill Of Material (BOM) we haven't estimated the Break Even Point.

\subsection{Bill of Material}

Bill of material of Multifunctional computer table is given below-

Table-8: Bill of Material (BOM) of Multifunctional computer table.

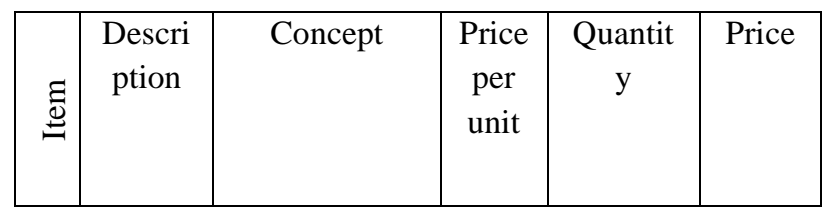




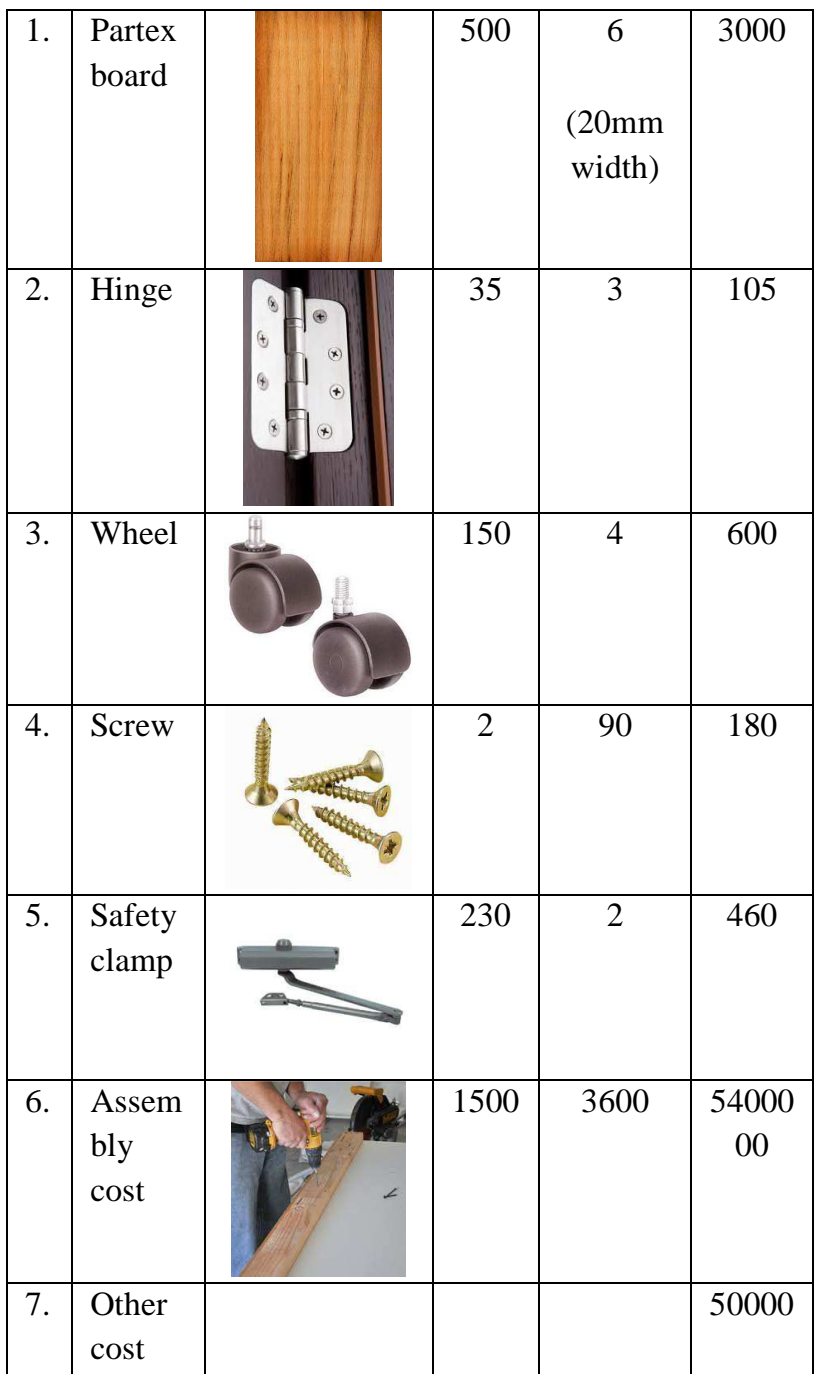

Material cost $=3000+105+600+180+460=4345$.

Fixed cost $=$ Assembly cost + other cost $=5400000+50000=$ 5450000 .

\subsection{Break-Even Point}

Break-even (or break even) is the point of balance between making either a profit or a loss. The term originates in finance, but the concept has been applied widely since.

\section{Break-even point of multifunctional computer table:}

Total cost of product $=($ Material cost $*$ no. of units $)+$ Fixed cost

$$
\mathrm{Y}_{\mathrm{cost}}=(4345 * \mathrm{X})+5450000
$$

Sales price of total product $=($ our sales rate $*$ no. of units $)$

$$
\mathrm{Y}_{\text {sales }}=(7000 * \mathrm{X})
$$

In break-even point,

$$
\begin{array}{cc}
\rightarrow & \text { Total cost }=\text { Total sale } \\
\rightarrow & \mathrm{Y}_{\text {cost }}=\mathrm{Y}_{\text {sales }} \\
\rightarrow & (4345 * \mathrm{X})+5450000=(7000 * \mathrm{X}) \\
\rightarrow & 2655 * \mathrm{X}=5450000 \\
\mathrm{X} & \mathrm{X}=2052.73 \\
& =2053
\end{array}
$$

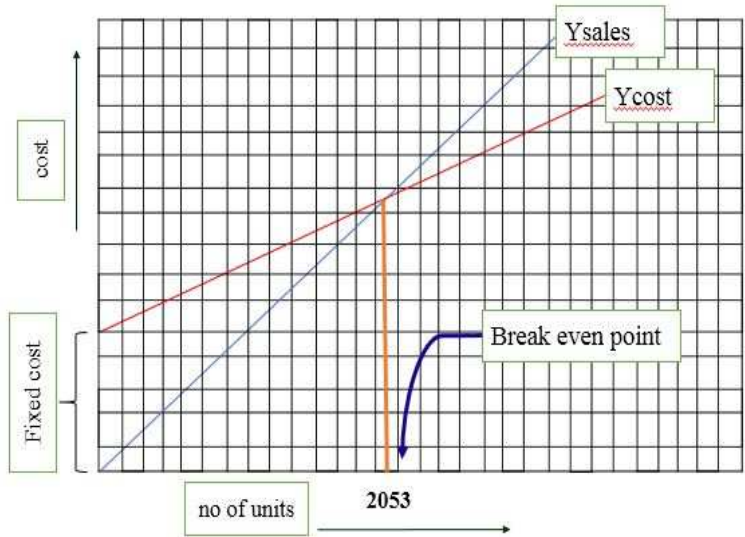

Chart-2: Break-even point of Multifunctional computer table.

So, the break-even point of our product is 2053 . We get the equivalence of cost and sales by selling 2053 pieces of tables. If we can sell one table after 2053 pieces that will be our profit. So, if we can sell all the tables around the year we will make the profit of $(3600-2053)=1547$ tables.

\section{CONCLUSIONS}

We have tried to present here the various stages of development activity of our product. What we have exercised, what we have thought and what we have planned to develop our product for customer satisfaction have been briefly discussed here because the main target of a business is to make as much as profit. We, the team members believe that our product will achieve a very strong position in this competitive market; and we are very hopeful.

\section{ACKNOWLEDGEMENTS}

Hundreds of people contributed for making this product in large and small ways. We are grateful to the many industrial practitioners and customers who provided data, examples and insights. We appreciate the assistance we have received from numerous academic friends, research assistants and support staff, from our sponsors. Indeed we could not have completed this project without the cooperation and collaboration of our honorable teachers. Thank you all. 


\section{REFERENCES}

[1]. Karl T. Ulrich, Steven D. Eppinger and Anita Goyal "Product Design and Development", "Tata McGraw Hill Edition 2009 ", $4^{\text {th }}$ edition, chapter-3 to chapter-8.

\section{BIOGRAPHIES}

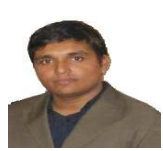

Ahasan Habib Lecturer, Industrial Engineering \& Management, Khulna University of Engineering \& Technology, Khulna, Bangladesh, shiplu04_ipe@yahoo.com

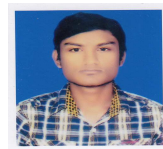

Ghazi Abu Taher $3^{\text {rd }}$ year Student BSC, Industrial Engineering \& Management, Khulna University of Engineering \& Technology, Khulna, Bangladesh ghaziabutaher@yahoo.com

Moumita Saha $3{ }^{\text {rd }}$ year Student BSC, Industrial Engineering \& Management, Khulna University of Engineering \& Technology, Khulna, Bangladesh, moumita.saha777@gmail.com 